\title{
Investigation of phytochemical contents, in vitro antioxidant and antibacterial behavior and in vivo anti-inflammatory potential of Ecballium elaterium methanol fruits extract
}

\author{
Samir FELHI ${ }^{1}$, Mongi SAOUDI ${ }^{2}$, Amal DAOUD ${ }^{1}$, Hafedh HAJLAOUI ${ }^{3}$, Marwa NCIR ${ }^{2}$, Rim CHAABANE , \\ Abdelfattah EL FEKI ${ }^{2}$, Néji GHARSALLAH ${ }^{1}$, Adel KADRI ${ }^{1,5 *}$
}

\begin{abstract}
Ecballium elaterium species are mostly used as therapeutic agents and food ingredient. The current work was designed to investigate phytochemical contents, antioxidant, antibacterial, and anti-inflammatory properties of methanol fruits extract of Ecballium elaterium. Good antioxidant activity was observed with $\mathrm{IC}_{50}$ values of $156 \pm 4$ and $377 \pm 6 \mu \mathrm{g} / \mathrm{mL}$ for DPPH and $\mathrm{ABTS}$, respectively, and $\mathrm{EC}_{50}$ of $126 \pm 4 \mu \mathrm{g} / \mathrm{mL}$ for FRAP assays, which is related with their richness in total phenolic, flavonoid and condensed tannins contents. The results of antibacterial activity showed the effectiveness of methanol extract against Bacillus cereus with value of inhibition zone diameter of $15 \pm 0 \mathrm{~mm}$ and a MIC and MBC values of $6 \pm 0$ and $12 \pm 0 \mathrm{mg} / \mathrm{mL}$, respectively. The in vivo anti-inflammatory effects have been also studied by carrageenan induced rat paw edema assay and the results revealed that a dose of $75 \mathrm{mg} / \mathrm{kg}$ induced a significant inhibition of $66.4 \%$ at $2 \mathrm{~h}$. FT-IR spectral data justified the presence of biological functional groups such as $-\mathrm{OH}, \mathrm{C}-\mathrm{H}, \mathrm{C}-\mathrm{O}, \mathrm{C}-\mathrm{C}$ and $\mathrm{C}=\mathrm{O}$. These results highlighted the potential using of Ecballium elaterium fruits extract as natural antimicrobial, antioxidant and anti-inflammatory agents for food applications and for the pharmaceutical industry.
\end{abstract}

Keywords: Ecballium elaterium methanol fruits extract; phytochemical contents; FT-IR analysis; in vitro antioxidant and antibacterial behavior; in vivo anti-inflammatory potential.

Practical Application: Ecballium elaterium is a medicinal plant which possess wide spectrum of different biological activities.

\section{Introduction}

Nowadays, increasing in prevalence of multiple drug resistance implies the development of new synthetic antibacterial, antioxidative and anti-inflammatory drugs from alternative sources (Papadoupoulo et al., 2005). Therefore, there is a renewed interest in natural substances containing phytoconstituents that exhibited several biological properties. They are used in health to prevent oxidative deterioration and some chronic diseases (Tel-Çayan et al., 2015). The development of phagocytes and the production of non-free radicals $\left(\mathrm{H}_{2} \mathrm{O}_{2}\right)$ and radicals of $\mathrm{O}_{2}$ and $\mathrm{OH}$ species induced many inflammatory disorders which caused many chronic diseases (Zeng et al., 2017). Medicinal plant therapy was well known for their richness in anti-inflammatory substances. In fact, herbal extracts and their major phytochemical compounds possess a good anti-inflammatory potential (Lee et al., 2011).

Ecballium elaterium (Cucurbitaceae) is known as a squirting cucumber, perennial herb that is largely abundant in Mediterranean region. Traditionally, this plant has been used for the treatment of fever, cancer, sinusitis, jaundice, constipation, hypertension and rhinosinusitis (Mazokopakis et al., 2009). The fruit juice was known for its antipyretic and analgesic potential. The roots and fruits extracts of this plant has been used as a curative. In Tunisia, the plant is widely consumed as infusion and used for the treatment of sinusitis and rheumatic (Bizid et al., 2014).

This work was designed to evaluate the total phenolic, flavonoid, and condensed tannin of methanol extract of E. elaterium fruits as well as the identification by FT-IR of the main active functional groups, and to evaluate its in vitro antioxidant and antibacterial properties. It also aimed to determine for the first time the in vivo anti-inflammatory activity of methanol extract by carrageenan induced rat paw edema assay with histopathological and biochemical analysis.

\section{Materials and methods}

\subsection{Plant collection and preparation of extract}

The fruits of E. elaterium (L.) were collected in May 2015 from plants grown in the Sidi Bouzid province of Tunisia (latitude $35^{\circ} 02^{\prime} 17^{\prime \prime}$, longitude $9^{\circ} 29^{\prime} 05^{\prime \prime}$; elevation: $332 \mathrm{~m}$ ). After collection, the preparation of extract followed the same method as done by Yllmaz et al. (2017). 


\subsection{Total phenolic, total flavonoid, and tannin contents}

The phytochemical contents of methanol fruits extract were investigated according to the same protocol done by Mrabti et al. (2017). Tannin contents of extract were determined by the same test as used by Sun et al. (1998). Each test was performed thrice.

\subsection{Fourier Transform Infrared Spectroscopy (FT-IR)}

The FT-IR spectra of methanol fruits extract were recorded with at room temperature on a Universal ATR Sampling Accessory infrared spectrophotometer. Dried paste of extract was loaded on the sample chamber of FT-IR spectrophotometer and scanned with a scan range from 550 to $4000 \mathrm{~cm}^{-1}$ at a resolution of $4 \mathrm{~cm}^{-1}$.

\subsection{Antioxidant activities}

\section{DPPH and FRAP assays}

Measurements followed the same method as done by Amessis-Ouchemoukh et al. (2017).

\section{ABTS test}

In this assay we followed the same protocol as described by Re et al. (1999). Trolox was used as a reference.

\subsection{Screening of antibacterial activity}

The antibacterial activity of extract was tested against Gram positive bacteria Bacillus subtilis JN 934392, Bacillus cereus JN 934390, Staphylococcus aureus ATCC 6538 and Gram negative bacteria Escherichia coli ATCC 25922, Salmonella enteritidis, and Klebsiella pneumoniae. The determination of the inhibition zone diameter, minimum inhibitory concentration (MIC), and minimum bactericidal concentration (MBC) were based on the same method used by Mzid et al. (2017).

\subsection{In vivo anti-inflammatory activity}

Carrageenan-induced acute inflammatory model

Anti-inflammatory activity was measured using carrageenan induced rat paw edema assay as ascribed by Olajide et al. (2000) and Owoyele et al. (2004).

\section{Biochemical evaluation and histopathological analysis}

The biochemical and histopathological evaluation has been done using the same protocol of Saoudi \& El Feki (2012) and (Sadeghi et al., 2011), respectively.

\subsection{Statistical analysis}

The results were analyzed by SPSS, ANOVA variance and Tukey test for multiple comparisons. Differences were considered statistically significant at $p<0.05$.

\section{Results and discussion}

\subsection{Phytochemical contents}

The results indicated that phenolic, flavonoid and condensed tannin contents in methanol extract were found to be $93 \pm 2 \mathrm{mg} \mathrm{GAE} / \mathrm{g}, 7 \pm 1 \mathrm{mg} \mathrm{QE} / \mathrm{g}$ and $1 \pm 0 \mathrm{mg} \mathrm{CE} / \mathrm{g}$, respectively. These phytochemicals play a versatile role in curing many diseases. Therefore, we attempted to estimate the biological active functional groups in methanol E. elaterium extract of by FT-IR method.

\subsection{FT-IR spectral analysis of methanol extract}

FT-IR spectral analysis data for the methanol extract (Figure 1) revealed the existence of multiple biological active functional groups. For the higher wavenumbers, the absorption band at $3350.4 \mathrm{~cm}^{-1}$ was attributed to $-\mathrm{OH}$ stretching vibration specific of phenolic compounds which indicate hydroxyl groups exist in extract, while the peaks at 2924.3 and $2850.7 \mathrm{~cm}^{-1}$ were due to $\mathrm{CH}_{2}$ anti-symmetric stretch of methyl groups mainly from lipids. The absorption peaks around 1746.1 and $1635.1 \mathrm{~cm}^{-1}$ are assigned to the stretching vibration of carbonyl group and to ring $\mathrm{C}-\mathrm{C}$ stretch of phenyl, respectively. The presence of peak at $1372.66 \mathrm{~cm}^{-1}$ respectively, is due to the in-plane $\mathrm{C}-\mathrm{O}$ stretching vibration combined with the ring stretch of phenyl. Between 1200 and $1050 \mathrm{~cm}^{-1}$, one can observe a stretching absorption band of $\mathrm{C}-\mathrm{O}$ for phenols. The "shoulder" peak at $1160.0 \mathrm{~cm}^{-1}$ is from carbohydrate, whereas the absorptions bands at 1055.4 and $984.0 \mathrm{~cm}^{-1}$ are derived from the vibrational frequency of the $\mathrm{CH}_{2} \mathrm{OH}$ groups of carbohydrates.

\subsection{Antioxidant activity}

DPPH radical scavenging assay: The antioxidant potential of methanol fruits extract of E. elaterium was estimated in terms of $\mathrm{IC}_{50}$ (i.e., the concentration required to scavenge $50 \%$ of the initial DPPH radicals). Five concentrations $(50,100,200,400$ and $500 \mu \mathrm{g} / \mathrm{mL})$ were used and the $\%$ inhibition and $\mathrm{IC}_{50}$ values were presented in Table 1 . We observed that scavenging capacity strongly enhanced with concentration in the range of $50-500 \mu \mathrm{g} / \mathrm{mL}$ and the results were statistically significant $(p<0.05)$.

In this assay, methanol fruit extract maybe participate as hydrogen-donating. Our results revealed significant correlations between phenolic compounds and antioxidant properties in methanol fruit extract and DPPH scavenging, in agreement with Daffodil et al. (2012) because of their redox properties and to

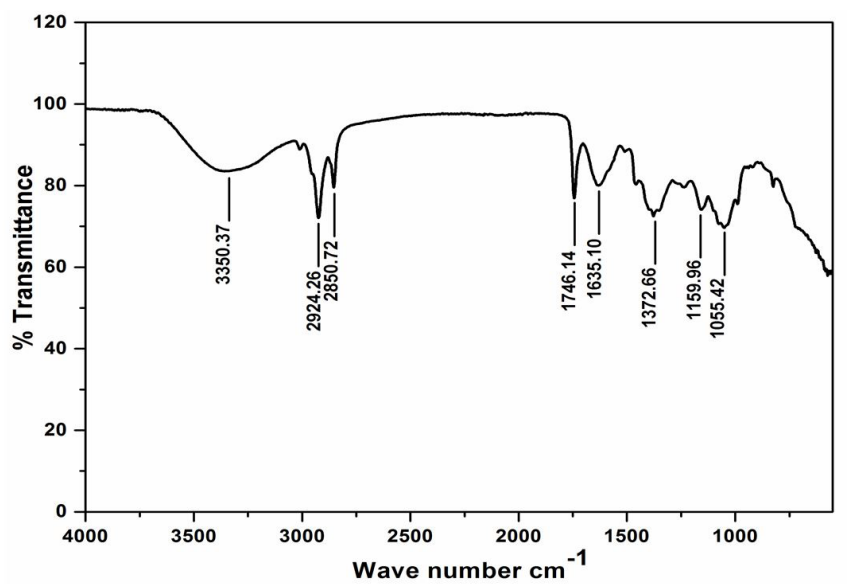

Figure 1. FT-IR spectra of methanol fruits extract of E. elaterium. 
the existence of free $\mathrm{OH}$ groups that act as donating hydrogen and therefore to remove the extra electron (Lobo et al., 2010).

ABTS radical scavenging assay: ABTS method is widely used to estimate antioxidant activity in foods and biological systems. The scavenging ability of methanol fruits extract of E. elaterium was expressed in terms of percentage of inhibition and $\mathrm{IC}_{50}$ values (Table 1 ). The results were dose dependent manner and statistically significant $(p<0.05)$.

The scavenging ability of ABTS ${ }^{\bullet+}$ could presumably related to the richness of extract in phenolics compounds, which can act as electron donors by reacting with free radicals. Hagerman et al. (1998) reported that tannins are powerful compounds for soaking free radicals $\left(\mathrm{ABTS}^{\bullet}\right.$ ). Higher scavenging antiradical effect with ABTS method may be due to the higher contents of polyphenolics in this extract.

Ferric reducing power: As depicted in Table 1, reducing capacity of the same extract significantly $(p<0.05)$ increased with increasing in concentration $(50-400 \mu \mathrm{g} / \mathrm{mL})$. The obtained results suggest that E. elaterium may have important applications in the future as a good source of natural antioxidants for plant-based food products.

\subsection{Antibacterial activity}

The results depicted in Table 2 showed that methanol fruit extract were more effective against Bacillus cereus with an inhibition zone diameter of $15 \pm 0 \mathrm{~mm}, \mathrm{MIC}$ of $6 \pm 0 \mathrm{mg} / \mathrm{mL}$, and $\mathrm{MBC}$ of $12 \pm 0 \mathrm{mg} / \mathrm{mL}$. In the same way, the extract showed an interesting activity against $S$. enteritidis with inhibition zone diameter, MIC, and MBC values of $12 \pm 0 \mathrm{~mm}, 12 \pm 0$ and $25 \pm 0 \mathrm{mg} / \mathrm{mL}$, respectively. While the other bacteria showed moderate sensitivity toward the tested extract with inhibition zone diameter ranging from $8 \pm 1$ to $9 \pm 1 \mathrm{~mm}$.

Sasmakov et al. (2012) study justified that methanol extract of E. elaterium had weaker activity against $S$. aureus (ATCC 29213) with inhibition zone diameter of $8 \pm 0 \mathrm{~mm}$, and negative activity against B. subtilis (ATCC 6059) and E. coli (ATCC 25922), these results are different to our study. In agreement with the report of Chamandi et al. (2015), an extract is bacteriostatic

Table 1. The inhibitory effects of methanol fruits extract of E. elaterium on DPPH, ABTS scavenging activities and ferric reducing power assay.

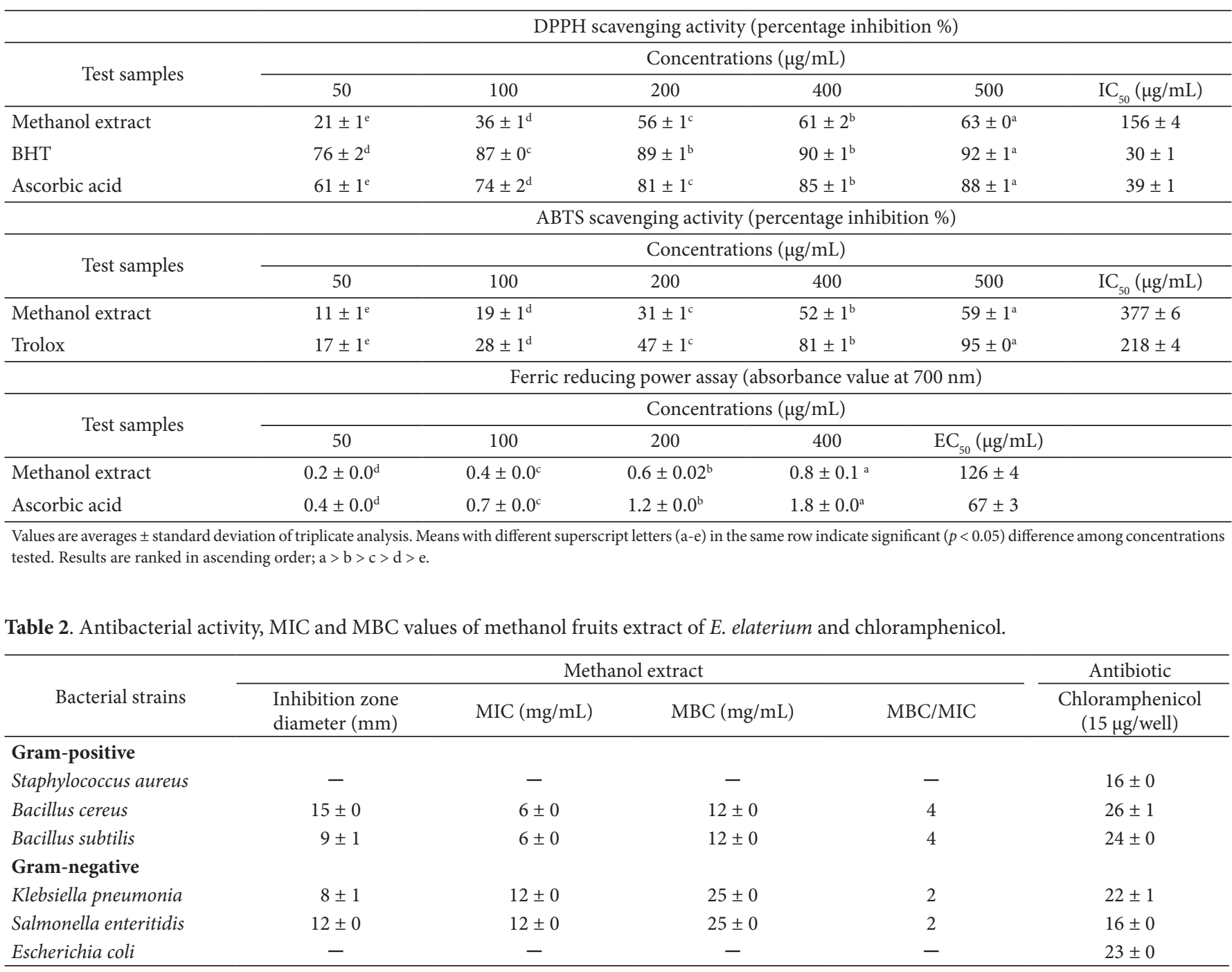

Data are mean \pm standard deviation of three individual determinations. (-): Not detected. 
when $\mathrm{MBC} / \mathrm{MIC} \geq 4$ and bactericidal if $\mathrm{MBC} / \mathrm{MIC} \leq 4$. Based on this study, it can be concluded that methanol extract of E. elaterium have a bacteriostatic and bactericidal effect on Gram-positive and Gram-negative, respectively. The differential sensitivity of Gram-positive and Gram-negative bacteria to plant extract may be explained by the morphological differences between the microorganisms. In this study, the Gram-negative isolates were less susceptible to the plant extracts than the Gram-positive bacterial isolates. In fact, the strongly resistance of Gram-negative bacteria was accredited to the complexity of the double membrane including cell envelope, that be expressed by lipoprotein and lipopolysaccharide, and which plays the role of a barrier to the antibacterial substances, contrasted to the single membrane structure of Gram-positive bacteria. A shown, antibacterial behavior may be related to the richness of this extract in bioactive components. This superior antibacterial property may be related to the higher contents of polyphenolics in this extract. Our results clearly demonstrate the possibility to use E. elaterium fruits as a source of new antibacterial agents of multiple-barrier food preservation systems.

\subsection{Anti-inflammatory studies}

The results showed that pre-treatement of rats with the extract $(75 \mathrm{mg} / \mathrm{kg})$ showed significantly reduced paw edema from $1 \mathrm{~h}$ until $5 \mathrm{~h}$ (Figure 2 and Table 3). The highest inhibition of edema obtained by the extract with $75 \mathrm{mg} / \mathrm{kg}$ dose was $66.4 \%$ at $2 \mathrm{~h}$. The extract compared effectively with standard drug indomethacin $(10 \mathrm{mg} / \mathrm{kg})$ used in this study, which produced a peak inhibition of edema (72.6\%) at $2 \mathrm{~h}$.

Our results showed that the methanol fruits extract of E. elaterium exerted higher anti-inflammatory potential. The extract also inhibited the inflammatory processes of intraperitoneal injection administration at low dose. Herbals can to synthesize a large variety of chemical compounds with beneficial effects on health. It has been reported that certain flavonoids have an inhibitory effect against histamine release in mast cells (Weng et al., 2012).
By their anti-inflammatory potential, flavonoids can interact directly with the prostaglandins system like the non-steroidal anti-inflammatory drugs (Aro et al., 2016). So, this activity was correlated to the richness of this extract in flavonoids and tannins and therefore, justified clearly that E. elaterium fruits may be used for the treatment of chronic inflammation.

Biochemical evaluation: The administration of carrageenan in rats induced a significantly increase in AST, ALT, ALP, Ferritine and CK levels as compared to control vehicle rats. The methanol fruits extract of E. elaterium and indomethacin reduced significantly the elevated levels of serum AST, ALT, ALP, Ferritine and $\mathrm{CK}$ as compared to untreated rats and carrageenan rats alone (Table 4). The above results are consistent with the reports of Sengar et al. (2015) which verified that AST, ALT and ALP enzymes were enhanced in both acute and sub-chronic inflammation. Sengar et al. (2015) confirmed that extract of Jasminum sambac at $400 \mathrm{mg} / \mathrm{kg}$ (p.o) considerably restored the AST and ALT level but without alteration in ALP level.

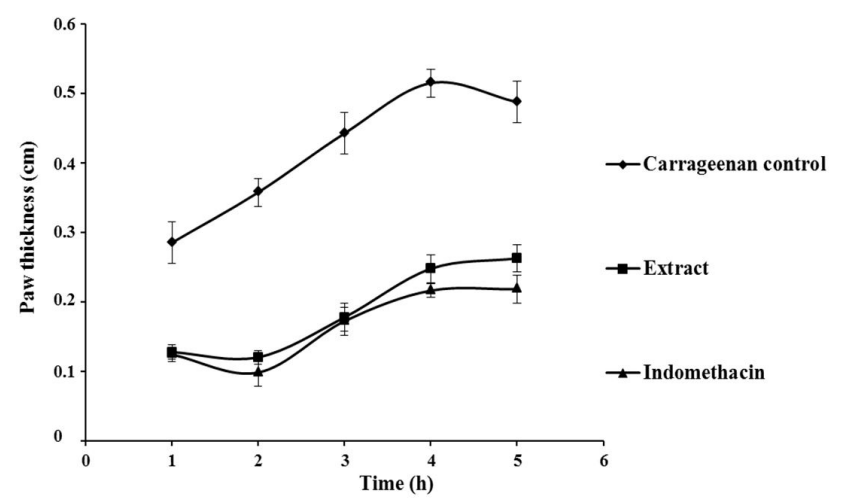

Figure 2. Effects of methanol fruits extract of E. elaterium on carrageenan-induced rat paw edema model. Values are mean \pm standard deviation.

Table 3. Effects of methanol fruits extract of E. elaterium and indomethacin of on carrageenan-induced hind paw edema in rats.

\begin{tabular}{|c|c|c|c|c|c|c|}
\hline \multirow{3}{*}{ Group } & \multirow{3}{*}{ Dose $(\mathrm{mg} / \mathrm{kg})$} & \multicolumn{5}{|c|}{ Time after carrageenan injection } \\
\hline & & $1 \mathrm{~h}$ & $2 \mathrm{~h}$ & $3 \mathrm{~h}$ & $4 \mathrm{~h}$ & $5 \mathrm{~h}$ \\
\hline & & \multicolumn{5}{|c|}{ Mean paw diameter (\% inhibition) } \\
\hline Indomethacin & 10 & $0.1 \pm 0.0^{* * *}(56.5)$ & $0.1 \pm 0.0^{* * *}(72.6)$ & $0.2 \pm 0.0^{\star * *}(61.1)$ & $0.2 \pm 0.0^{* * *}(58.0)$ & $0.2 \pm 0.0^{\star \star \star}(55.3)$ \\
\hline Extract & 75 & $0.1 \pm 0.0^{* * *}(55.3)$ & $0.1 \pm 0.0^{\star * *}(66.4)$ & $0.2 \pm 0.0^{* * *}(59.9)$ & $0.2 \pm 0.0^{* * *}(51.9)$ & $0.3 \pm 0.1^{\star \star *}(46.1)$ \\
\hline
\end{tabular}

Significant differences: Values are mean \pm standard error of mean $(n=6){ }^{* * *} p<0.001$ vs. vehicle control.

Table 4. Serum biochemistry changes of control and rats treated with carrageenan, carrageenan + extract and carrageenan + Indomethacin.

\begin{tabular}{lcccc}
\hline \multicolumn{1}{c}{ Treatment and } & \multicolumn{3}{c}{ Experimental groups } \\
\cline { 2 - 5 } parameters & Vehicle control & Carrageenan control & Carr+extract & Carr+Ind \\
\hline AST (UI/L) & $241 \pm 3$ & $306 \pm 52^{*}$ & $259 \pm 24^{*}$ & $299 \pm 41^{\star}$ \\
ALT (UI/L) & $36 \pm 2$ & $47 \pm 9^{*}$ & $38 \pm 5^{*}$ & $43 \pm 2^{\star}$ \\
ALP (UI/L) & $216 \pm 6$ & $233 \pm 32$ & $238 \pm 8^{*}$ & $227 \pm 21$ \\
Ferritine (ng/ml) & $1.5 \pm 0.1$ & $1.7 \pm 0.1^{\star *}$ & $1.6 \pm 0.1^{*}$ & $1.5 \pm 0.0^{*}$ \\
CK (UI/L) & $10527 \pm 754$ & $13032 \pm 3448^{*}$ & $10907 \pm 1486$ & $11421 \pm 1263$ \\
\hline
\end{tabular}

Significant differences: Values are mean \pm standard error of mean $(\mathrm{n}=6) .{ }^{*} p<0.05 ;{ }^{*} p<0.01$ vs. vehicle control; Carrageenan group vs Carr+extract group and Carr + Ind; ${ }^{*} p<0.05$. 

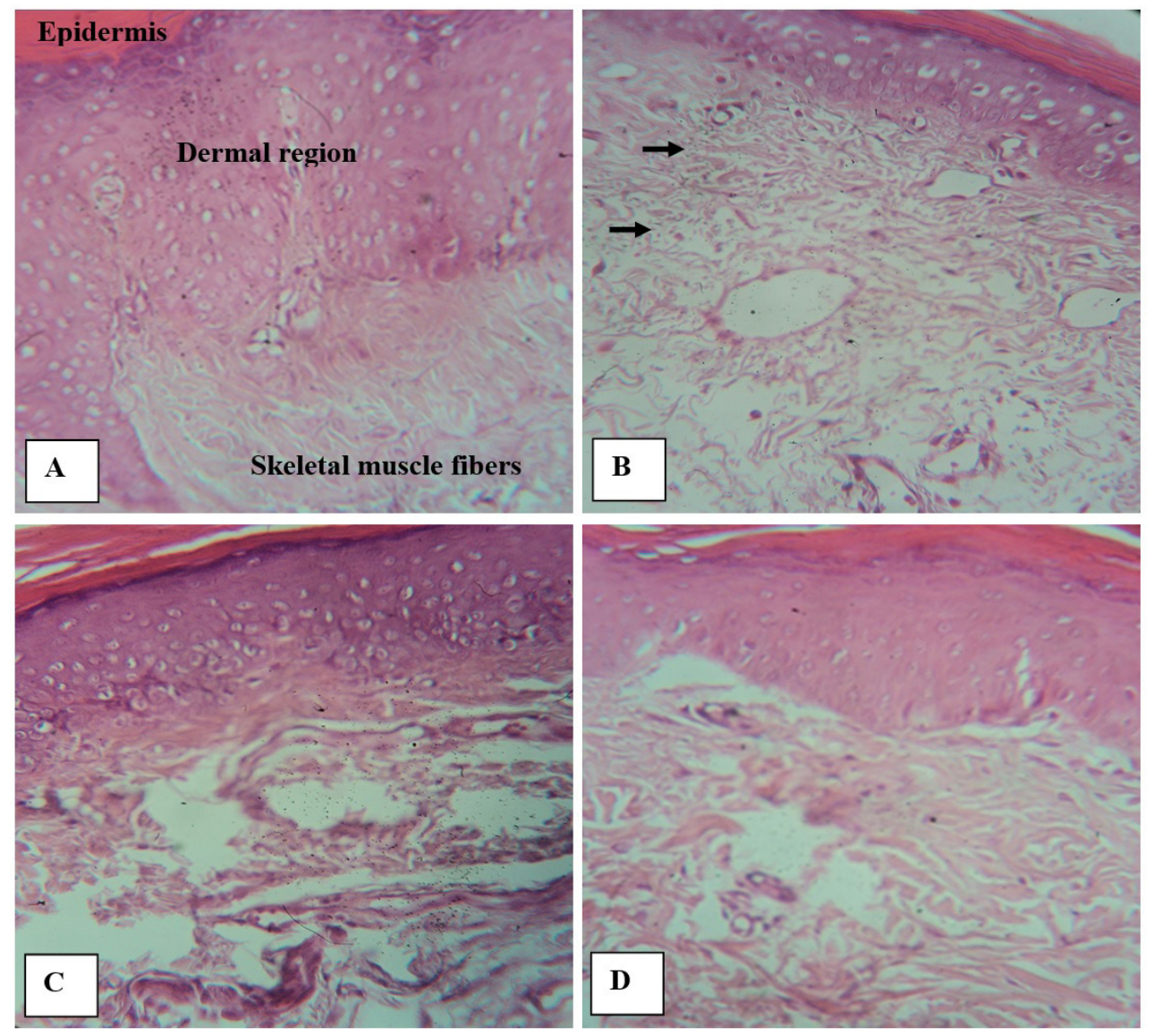

Figure 3. Histopathological examinations on carrageenan induced edema paw tissues after treatments. Histological evaluation was performed by hematoxylin and eosin staining. A: normal rats showed the normal appearance of epidermis and dermis without any lesion; B: carrageenan injected paw skin in control group (vehicle-treated) showed edema and accumulation of infiltrating inflammatory cells (arrow); C: carrageenan injected paw skin of rats treated with methanol fruits extract of E. elaterium showed that edema and inflammatory cells accumulation reduced; D: carrageenan injected paw skin of rats treated with indomethacin showed that the migration of inflammatory cells reduced.

Histopathological findings: Histological investigation was examined by hematoxylin and eosin staining. High infiltration damage due to accumulation of infiltrating inflammatory cells was observed for Group B. However, the vehicle control Group A was devoid in inflammation and the infiltration damage was moderated in the methanol fruits extract of E. elaterium and indomethacin drug treatment groups compared to high level of infiltrating inflammatory cells in Group B (Figure 3). Similar studies were conducted previously by Maleki et al. (2001) which demonstrated the protective effects of the hydroalcoholic extract of Stachys inflata aerial parts of against carrageenan induced histopathological paw tissue and the results found in this study also support the facts. These findings provide the potential use of E. elaterium as a good source of anti-inflammatory agents, or food supplement for prevention of chronic diseases.

\section{Conclusions}

The results suggest that E. elaterium fruits extract contain a wide range of phenolics, flavonoids and condensed tannins contents, associated with potent pharmacological activities. From this study it can be suggested that the tested E. elaterium fruits extract have potential antioxidant behavior. The results show also that the extract exhibited a higher antibacterial activity which can be used as a potent antibacterial agent against Bacillus cereus. Besides, the extract was found to possess considerable anti-inflammatory properties at dose tested, and could have significant effect against chronic inflammation. We confirmed in this study the useful of $E$. elaterium as a promising plant for food industry. The methanol fruits extract of E. elaterium needed more investigation in order to identify the major active compounds and to demonstrate their mode of action.

\section{Acknowledgements}

Thanks to Pr. Leila Mahfoudhi from the English Language Unit, FSS, Tunisia for her valuable language polishing and editing services.

\section{References}

Amessis-Ouchemoukh, N., Ouchemoukh, S., Meziant, N., Idiri, Y., Hernanz, D., Stinco, C. M., Rodríguez-Pulido, F. J., Heredia, F. J., Madani, K., \& Luis, J. (2017). Bioactive metabolites involved in the antioxidant, anticancer and anticalpain activities of Ficus carica L., Ceratonia siliqua L. and Quercus ilex L. extracts. Industrial Crops and Products, 95, 6-17. http://dx.doi.org/10.1016/j.indcrop.2016.10.007. 
Aro, A. O., Dzoyem, J. P., Eloff, J. N., \& McGaw, L. J. (2016). Extracts of six Rubiaceae species combined with rifampicin have good in vitro synergistic antimycobacterial activity and good anti-inflammatory and antioxidant activities. BMC Complementary and Alternative Medicine, 16(1), 385. PMid:27716160. http://dx.doi.org/10.1186/ s12906-016-1355-y.

Bizid, S., Sabbah, M., Msakni, I., Slimene, B., Mohamed, G., Bouali, R., Abdallah, H., \& Abdelli, N. (2014). Cholestatic hepatitis due to Ecballium elaterium ingestion. Clinics and Research in Hepatology and Gastroenterology, 39(5), e61-e63. PMid:25573494. http://dx.doi. org/10.1016/j.clinre.2014.11.004.

Chamandi, G., Olama, Z., \& Holail, H. (2015). Antimicrobial effect of Propolis from different geographic origins in Lebanon. International Journal of Current Microbiology and Applied Sciences, 4(4), 328-342.

Daffodil, E. D., Rajalakshmi, K., \& Mohan, V. R. (2012). Estimates total phenolic, flavonoid content and in vitro antioxidant activity of root of Suaeda monaica Forssk ex Gmel (Chenopodiaceae). Elixir Applied Botany, 53, 11885-11889.

Hagerman, A. E., Riedl, K. M., Jones, G. A., Sovik, K. N., Ritchard, N. T., Hartzfeld, P. W., \& Riechel, T. L. (1998). High molecular weight plant polyphenolics (tannins) as biological antioxidants. Journal of Agricultural and Food Chemistry, 46(5), 1887-1892. http://dx.doi. org/10.1021/jf970975b.

Lee, K. H., Padzil, A. M., Syahida, A., Abdullah, N., Zuhainis, S. W., Maziah, M., Sulaiman, M. R., Israf, D. A., Shaari, K., \& Lajis, N. H. (2011). Evaluation of anti-inflammatory, antioxidant and antinociceptive activities of six Malaysian medicinal plants. Journal of Medicinal Plant Research, 5(23), 5555-5563.

Lobo, V., Patil, A., Phatak, A., \& Chandra, N. (2010). Free radicals, antioxidants and functional foods: impact on human health. Pharmacognosy Reviews, 4(8), 118-126. PMid:22228951. http:// dx.doi.org/10.4103/0973-7847.70902.

Maleki, N., Garjani, A., Nazemiyeh, H., Nilfouroushan, N., Sadat, E. A. T., Allameh, Z., \& Hasannia, N. (2001). Potent anti-inflammatory activities of hydroalcoholic extract from aerial parts of Stachys inflata on rats. Journal of Ethnopharmacology, 75(2-3), 213-218. PMid:11297854. http://dx.doi.org/10.1016/S0378-8741(01)00194-5.

Mazokopakis, E. E., Karefilakis, C. M., \& Starakis, I. K. (2009). The safety and efficacy of the fruit juice of Ecballium elaterium in the treatment of acute rhinosinusitis. Journal of Alternative and Complementary Medicine (New York, N.Y.), 15(12), 1273-1274. PMid:19958105. http://dx.doi.org/10.1089/acm.2009.0241.

Mrabti, H. N., Marmouzi, I., Sayah, K., Chemlal, L., El Ouadi, Y., Elmsellem, H., Cherrah, Y., \& Faouzi, M. A. (2017). Arbutus unedo $\mathrm{L}$ aqueous extract is associated with in vitro and in vivo antioxidant activity. Journal of materials and Environmental Sciences, 8(1), 217-224.

Mzid, M., Ben Khedir, S., Ben Salem, M., Regaieg, W., \& Rebai, T. (2017). Antioxidant and antimicrobial activities of ethanol and aqueous extracts from Urtica urens. Pharmaceutical Biology, 55(1), 775-781. PMid:28084125. http://dx.doi.org/10.1080/13880209.2016.1275025.

Olajide, O. A., Awe, S. O., Makinde, J. O., Ekhelar, A. I., Olusola, A., Morebise, O., \& Okpako, D. T. (2000). Studies on the anti-inflammatory, antipyretic and analgesic properties of Alstonia boonei stem bark. Journal of Ethnopharmacology, 71(1-2), 179-186. PMid:10904161. http://dx.doi.org/10.1016/S0378-8741(99)00200-7.
Owoyele, B. V., Wuraola, C. O., Soladoye, A. O., \& Olaleye, S. B. (2004). Studies on the antiinflammatory and analgesic properties of Tithonia diversifolia leaf extract. Journal of Ethnopharmacology, 90(2-3), 317321. PMid:15013196. http://dx.doi.org/10.1016/j.jep.2003.10.010.

Papadoupoulo, C., Soulti, K., \& Roussis, I. G. (2005). Potential antimicrobial activity of red and white wine phenolic extracts against strains of Staphyloccocus aureus, Escherichia coli and Candida albicans. Food Technology and Biotechnology, 43(1), 41-46.

Re, R., Pellegrini, N., Proteggente, A. E., Pannala, A., Yang, M., \& Rice-Evans, C. (1999). Antioxidant activity applying an improved ABTS radical cation decolourization assay. Free Radical Biology \& Medicine, 26(9-10), 1231-1237. PMid:10381194. http://dx.doi. org/10.1016/S0891-5849(98)00315-3.

Sadeghi, H., Hajhashemi, V., Minaiyan, M., Movahedian, A., \& Talebi, A. (2011). A study on the mechanisms involving the antiinflammatory effect of amitriptyline in carrageenaninduced paw edema in rats. European Journal of Pharmacology, 667(1-3), 396-401. PMid:21645506. http://dx.doi.org/10.1016/j.ejphar.2011.05.053.

Saoudi, M., \& El Feki, A. (2012). Protective role of Ficus carica stem extract against hepatic oxidative damage induced by methanol in male Wistar rats. Evidence-Based Complementary and Alternative Medicine, 2012, 1-8. http://dx.doi.org/10.1155/2012/150458.

Sasmakov, S. A., Putieva, Z. M., Azimova, S. S., \& Lindequist, U. (2012). In vitro screening of the cytotoxic, antibacterial and antioxidant activities of some Uzbek plants used in folk medicine. Asian Pacific Journal of Tropical Medicine, 7, 75-80.

Sengar, N., Joshi, A., Prasad, S. K., \& Hemalatha, S. (2015). Antiinflammatory, analgesic and anti-pyretic activities of standardized root extract of Jasminum sambac. Journal of Ethnopharmacology, 160, 140-148. PMid:25479154. http://dx.doi.org/10.1016/j.jep.2014.11.039.

Sun, B., Richardo-da-Silvia, J. M., \& Spranger, I. (1998). Critical factors of vanillin assay for catechin and proanthocyanidins. Journal of Agricultural and Food Chemistry, 46(10), 4267-4274. http://dx.doi. org/10.1021/jf980366j.

Tel-Çayan, G., Öztürk, M., Duru, M. E., Rehman, M. U., Adhikari, A., Türkoğlu, A., \& Choudhary, M. I. (2015). Phytochemical investigation, antioxidant and anticholinesterase activities of Ganoderma adspersum. Industrial Crops and Products, 76, 749-754. http://dx.doi.org/10.1016/j.indcrop.2015.07.042.

Weng, Z., Zhang, B., Asadi, S., Sismanopoulos, N., Butcher, A., Fu, X., Katsarou-Katsari, A., Antoniou, C., \& Theoharides, T. C. (2012). Quercetin is more effective than cromolyn in blocking human mast cell cytokine release and inhibits contact dermatitis and photosensitivity in humans. PLoS One, 7(3), e33805. PMid:22470478. http://dx.doi. org/10.1371/journal.pone.0033805.

Zeng, Y., Li, Y., Yang, J., Pu, X., Du, J., Yang, X., Yang, T., \& Yang, S. (2017). Therapeutic role of functional components in Alliums for preventive chronic disease in human being. Evidence-Based Complementary and Alternative Medicine, 2017, 1-13. https://doi. org/10.1155/2017/9402849.

Yılmaz, A., Yıldız, S., Kılıç, C., \& Can, Z. (2017). Total phenolics, flavonoids, tannin contents and antioxidant properties of Pleurotus ostreatus cultivated on different wastes and sawdust. International Journal of Secondary Metabolite, 4(1), 1-9. http://dx.doi.org/10.21448/ ijsm.252052. 